This is a preprint version of this article Karen Crawley and Kieran Tranter 'A Maelstrom of Bodies and Emotions and Things: Spectatorial Encounters with the Trial' (2019) International Journal for the Semiotics of Law DOI 10.1007/s11196-019-09618-3. The final version is available at https://link.springer.com/article/10.1007/s11196-019-096183?wt_mc=Internal.Event.1.SEM.ArticleAuthorOnlineFirst\&utm_source=A $\underline{\text { rticleAuthorOnlineFirst\&utm medium=email\&utm_content=AA en } 0608}$ 2018\&ArticleAuthorOnlineFirst_20190309

\title{
A Maelstrom of Bodies and Emotions and Things: Spectatorial Encounters with the Trial
}

Karen Crawley ${ }^{1}$ and Kieran Tranter ${ }^{2}$

\begin{abstract}
This paper explores spectatorial encounters with criminal trials. Particularly focusing on the 2018 work of Australian contemporary visual artist Julie Fragar that followed her watching murder trials in the Supreme Court of Queensland, it is argued that the artist as a legal outsider grapples with the inhumanity of the trial. This grappling can go in two directions. For some there is a need to bring the human back, to see the person beneath the mask of the role that they are performing, to connect the gothic horror of the trial back to a redeeming humanism. For others, and this is evident in Fragar, the horror of the inhumanity is visceral and overpowering, and the grotesque masque of judgment needs to be witnessed. Both perform a corrective and critique to the business as usual of processing, judging and stamping onto human lives that is legal insider's performance in the criminal trial.
\end{abstract}

\footnotetext{
${ }^{1}$ Senior Lecturer, Griffith Law School, Griffith University, Australia.

${ }^{2}$ Professor and Chair of Law, Technology and Future, School of Law, Queensland University of Technology, Australia. 
Keywords: criminal trial, spectatorship, artist, horror

\section{Introduction}

The criminal trial is a complex performance of space and bodies, of forms and formalism, of words spoken and ritual undertaken. For the criminal lawyer the performance of the trial is mundane and technical. The semiotics of the courtroom, the roles and responsibilities of the various actors, the robes and roles, the difference of the trial as a social space from everyday physical and semantic habitats recedes. The trial is a workplace in which prosaic jobs are done.

The familiarity of the criminal trial for lawyers obscures that it is not a familiar nor comfortable space for law's subjects. From the vantage point of the legal outsider, the trial is alien, indecipherable and exotic. The trial is not the manifestation of rules and practices that have a comprehensible purpose and history, as it is for the legal insider. Rather for the outsider witnessing the spectacle of the trial it can be seen as a strange affective performance where a maelstrom of bodies and emotions and things manifest within an intense, enclosed space.

This paper explores this tension between the legal insider's and outsider's responses to the criminal trial. In particular, it focuses on how the trial is represented in the work of artists who have witnessed trials. It is argued that the artist as outsider grapples with the inhumanity of the trial. This grappling can go in two directions. For some there is a need to bring the human back, to see the person beneath the mask of the role that they are performing, to connect the gothic horror of the trial back to a modernist humanism. For others the horror of the inhumanity is visceral and overpowering, and the grotesque masque of judgment needs to be seen. Both can be a critique and corrective to the business as usual processing, judging and stamping onto human lives that is legal insider's performance in the criminal trial.

This argument is in three parts. The first part examines the tradition of the legal outsider as a spectator of the courtroom. It shows how this external witnessing can expose the inhuman 
horror of the criminal trial. The second part considers work by the Australian novelist, writer and commentator Helen Garner and by the United Kingdom courtroom sketch artist Isobel Williams. Both respond to the inhuman horror of the trial by striving for humanity. Their witnessing involves a bringing of the singular lived beauty of individuals back into focus. The third part considers the work of Brisbane-based visual artist Julie Fragar, whose paintings emerged from time spent witnessing murder trials in the Supreme Court of Queensland. Unlike Garner and Williams who could be seen as not truly outsiders - Garner a member of the literary elite, familiar and experienced with law and legal institutions, and Williams an artist who repeatedly watches, draws and blogs about trials - Fragar came to the murder trials that she observed as an outsider. Her work is not a corrective to inhuman horror of the trial, rather a critique. The human is in flux and contested in Fragar's work and humanism is distinctly not redeeming. Rather there a maelstrom of bodies and emotions and things. Fragar's images forensically examine the horror: there are monsters and violations, disconcerting movement and a lack of distinction, no colour, and rather than the crisp black and white of text on paper, blurred greys.

\section{The Legal Outsider as Spectator of the Courtroom}

Visuality is considered a hallmark of a just, functioning criminal law. There is a need to be witnessed, deep in the foundations of criminal law. However, seeing does not mean understanding. In needing witnesses, in requiring spectators, the criminal law exposes the spectacle of the trial to outsiders. This part traces how law is interested in establishing an eyeball authority, an authority that is just seen. However, to invite an outsider into the trial there is a danger that they might not see legitimate authority and justice being done. The critical legal tradition suggests that when seeing a trial what is revealed is the essential violence of law. This part concludes with the suggestion that raw witnessing of the arcane performance of a trial is likely to show an inhuman horror.

The tradition of English criminal justice depends on an audience. Publicity, wrote Jeremy Bentham, is 'the very soul of justice.... It keeps the judge himself while trying under trial.' ${ }^{3}$ The integrity of criminal proceedings is bound up in their being held in public places in which

\footnotetext{
3 'Draught of a Code for the Organisation of the Judicial Establishment in France' (1790), in The Works of Jeremy Bentham, ed. John Bowring, 11 vols. (Edinburgh: William Tait, 1838-43), 4:316 cited in [23: 1]. 
spectators unconnected with the trial are able to observe justice being done [29, 85]. For A V Dicey, the rule of law demanded that courts operate openly and not in secret distinguishing their activities from administrative officials [8]. The concern is that if courts are not on public view, the administration of justice may be corrupted. A public hearing is a right enshrined in article 14(1) of the International Covenant on Civil and Political Rights. It is article of faith for modern legality that public trials supposedly improve the quality of courtroom testimony, making the judicial system more comprehensible to the public, reassuring the accused and the victim's families that the trial was conducted fairly and the accused treated justly. This desire to be seen further grounds the law's enlisting of the fourth estate. As the Australian Full Federal Court declared:

Exposure to public security is the surest safeguard against any risk of the courts abusing their considerable powers. As few members of the public have the time, or even the inclination, to attend courts in person, in a practice sense this principle demands that the media be free to report what goes on in them [30].

Crucially, a criminal trial must have an audience not only for them to observe that justice is being carried out, but to be co-opted into participating in a performance of legal authority. As scholars of legal history and legal aesthetics have long recognised, the staging of trials - their language, rituals, costumes and architecture - is intended to enact the law's authority and legitimise the exercise of power. ${ }^{4}$ The importance of ritual, symbolism and theatre within the English criminal justice system is well known. The law's constitutive dependence on such theatricality is a double-edged sword: in order to preserve its own claims to impartiality and rationality, the law must suppress its own tendency towards spectacular, emotional, visual theatricality [29: 181-2]. Trials are an occasion for the law to formally and solemnly perform its 'legitimised symbolic violence.' [2:835] 'Law’s force depends partly on the inscription on the soul of a regime of images.'[8: 9] As noted by many, notions of the majesty of law are given architectural form in the spatial differentiation of court buildings and courtrooms. The visual architecture of the court reflects a visual order, an aesthetic of power:

The power of spiritual, edifying icons is celebrated in every courtroom: in the wigs, robes and other theatrical paraphernalia of legal performance and in the images of

\footnotetext{
${ }^{4}$ See, for instance, the work of Peter Goodrich [15], [16], [17]. See also [18]. 
justice that adorn our public buildings. The law arranges, distributes, and polices its own image through icons of authority and sovereignty, tradition and fidelity [8]. For law and its discourse the performance of the courtroom is supposed to reflect the values of the rule of law - impartial judgment, formal equality - and to give the public faith in the courts and modernity's liberal legalism. To see the court this eyeball authority is supposed to reassure that this site, and its actors, can vindicate rights, remedy injustice and heal victims from acts of violence.

However, law in modernity has a notorious ambivalence towards images; notwithstanding its desiring of eyeball authority. In their seminal collection on law and images, Costas Douzinas and Lynda Nead explained that modern law is constituted by a rigid separation from aesthetic considerations and the aspirations of literature and art, and that the relationship between the aesthetic and the normative presented 'as one between pluralism and unity, surface openness and deep closure, figuration and emplotment.' [8: 3]. The self in art, as painter or viewer, is 'free, desiring corporeal,' with 'a gender and a history’; the subject of law, as judge or litigant, is 'constrained, censored and ethereal.' [8: 3]. Modern law manifested an ironic blindness: A blindness to its own reliance on the image. In doing so, it projects a simplistic visual jurisprudence. The claim is that simply seeing leads to acceptance. However, to desire the witnessing of outsiders is to invite a dangerous other into a legal space. This other might not comprehend the theatre of the trial as legitimate authority and justice, rather when witnessing the arcane performance of the trial generates alternative meanings.

The danger of inviting an other into a juridified space is not lost on law. The body of the spectator, eyeball and all, is not free. For the Supreme Court of Queensland the price of spectating is adherence to a regime of respectful etiquette; entering and leaving quietly, bowing to the judge, dressing appropriately, avoiding talking, eating and using mobile telephones. ${ }^{5}$ Linda Mulcahy has examined the changing relationship between the court and the public, noticing that the public's status within the courtroom has changed over time, from the more open courts of the eighteenth-century, towards gradual regulation of public behaviour and access borne of a slowly evolving fear and mistrust of the public and their interest in court proceedings [28]. During the eighteenth century the courts were regarded as 'legitimate places of entertainment' [28: 88] and were highly social spaces with men and women from a broad

\footnotetext{
${ }^{5}$ https://www.courts.qld.gov.au/going-to-court/courtroom-etiquette accessed 27 November 2018.
} 
range of social classes in regular attendance [28]; [6]. By the nineteenth century the 'idea of the spectator as someone who interrupts the business of the court had become a dominant narrative [28: 91]. This narrative saw an increasing emphasis on the distinction between the sacred majesty and authority of the courts [28: 84] and the unruly, vulgar and 'dirty' public. What can be seen in law's openness to audience is anxiety; that the state's solemn and ordered theatre of justice could be disrupted by a bawdy counter-theatre of populist justice of the mob [6].

Although modern day courtrooms appear to have a greater focus on inclusion and democratic participation in the administration of justice, Mulcahy argues modern initiatives to create a more welcome space may be nothing more than 'lip service' to the idea of the spectator as a welcome participant. The sacred space of the courts remains as a normative narrative and there is still a strong sense that the public is unpredictable, unruly and potentially disruptive [28: 967]. In Mulcahy's account, the architecture and design of the courtroom reveals 'the ideologies underpinning judicial process and power dynamics in the trial' [28: 106]. Mulcahy contends that the public has been relegated to the role of passive spectator rather than active participant and that 'the progressive use of segregation and surveillance to contain participants have served to undermine any meaningful aspiration to participatory justice or notions of the courtroom as public space’ [28: 106].

What this shows is the spectator is a dangerous, liminal figure. Desired by modern liberal legality for its eyeball, but not for its comprehension, the rules of court and the attitudes of the judiciary show a need to officiate on the mode of the spectator's seeing; an attempt to ensure that modern liberal legality's vision is correctly received. This discloses a deep anxiety that the arcane performance of the trial is not obviously and denotative of legitimate authority and justice, but to an outsider might reveal something else.

The critical legal tradition, instead of bolstering liberal claims to authority and justice, argues that the trial should reveal to the spectator the paradoxical relationship between law and violence. Law, in its modern liberal legalist guise, is supposed to be the opposite of violence; legal forms of decision-making interrupt the endless sequence of violence and counter-violence that characterises revenge, to exorcise or dispel or quell the violence generating more violence. Nevertheless, as Robert Cover eloquently explained, law, and particularly its material, 
institutional manifestations in courtrooms and trials, enacts forms of a violence [5]. Legal forms of decision-making exert violence that is both physical and psychic, battering the body and disciplining the soul: 'Legal interpretation takes place in a field of pain and death... A judge articulates her understanding of a text, and as a result, somebody loses his freedom, his property, his children, even his life.' [5: 1601-2]. For Christoph Menke, law overcomes the violence of revenge by recognising that 'there are two sides', which is why 'tragedy is the genre of law. The history of tragedy started when Aeschylus increased the number of actors to two' [26: 4]. For Menke:

Legal judging is different from all other violence; it is indeed the other of violation because it applies a general law, judges a violation in terms of general rules. Legal judgment and punishment bring the violence of revenge to an end, for what speaks through legal judgment and punishment is a law that is the same for all [26: 5].

Kieran Tranter has argued that the scope of law's violence under its urbane modern liberal mask goes to the demonic in its alchemical mixing of death and time [33: 58-75]. In the courtroom and in the trial this manifests in judges working with the primal material of time and space. As Mariana Valverde notes, the court is a 'chronotope,' [34: 16], a term she uses to explore the inextricability of time and space and to note how time 'thickens' and becomes spatialized in different legal processes [34: 11]. Valverde focuses on the temporal nature of the judge's power to start and stop proceedings, arguing that in spatiotemporal terms, the judge's sovereignty 'is greater than the judge's official legal power' [34: 17]. The time of the courtroom, reflected in the transcript, is ‘judge-centric discontinuous time.’ The judge’s power acts on and through the physical space of the courtroom; time 'thickens' space. A proper legal ruling has to be issued in a specific, consecrated indoor space at a particular time [34: 18].

For the critical legal tradition, witnessing a trial should reveal something very different to the legitimate authority and justice of modern liberal legality. Faced with incomprehensible images, the outsider is likely to see a surreal space; a space where violence is absent and present, a space where time and space bends and wobbles. This is particularly so in a criminal trial. There is an inhuman absence at the core of the criminal trial. The messy, violent details of the accused's wrongs against individual victims is transublimated into a generalised wrong against the state. Human and human lives are dissected and abstracted. This is particularly so in murder trials where the victim is dead and silent, unable to tell their story. The terrible 
absence of the deceased at the heart of murder trials acts as a vertiginous gravity, an incompleteness. Often family members attempt to tell the victim's stories in place of those who cannot speak, and sit prominently in a courtroom audience, in place of those who cannot listen [14: 867]. This is not seeing of legitimate authority and justice but a scene that is beyond normal, mundane interactions; a grotesque carnival where space, time and human lives are cut up, rearranged and spoken about in an arcane tongue. In terms of genre, the show of the trial is properly horror.

So while modern liberal legality requires the eyeball of the spectator to bolster an ideological commitment to justice needing to be seen, it does so with a knowing reluctance. To invite an outsider into the temple of the law is to expose its stages and actors, its images and actions, to a heathen's critique. Without the knowledge of a legal insider to decipher, the spectator is presented with a horrible and horrifying scene that is far removed from the everyday of human interaction. The raw images of the trial are an inhuman horror.

\section{Garner and Williams: Spectators as Humanist Redeemers}

Faced with making sense of the inhuman horror of the trial the spectator has several responses. Shutting one's eyes - refusing to be a co-opted eyeball for law's authority - is a response. This could be a valiant act of defiance or an affront to the ethics of witnessing. In this part the work of two artists, Helen Garner and Isobel Williams, who witnessed trials, is considered. Both took seriously an ethics of witnessing; that in seeing the face of the other demands a response and a memorialisation. It is argued that in their work both can be seen as responding to the inhuman horror of the trial with humanism. Presented with the atomising and abstracting of the trial, both re-humanise some of the human players -the victims, the accused, the lawyers, the judges - through piecing their bodies and lives back together, showing a totality to their existence and connections with others beyond the role.

Helen Garner's career as a novelist, journalist and, scriptwriter has spanned 40 years. She is celebrated as a leading Australian cultural voice and commentator [3]. In 2018 she was elected an Honorary Fellow of the Australian Academy of the Humanities. ${ }^{6}$ She has authored two books that emerged from her witnessing of criminal trials. The first, Joe Cinque's Consolation:

\footnotetext{
${ }^{6}$ https://www.humanities.org.au/2018/11/19/welcoming-28-newly-elected-fellows/ accessed 29 November 2018. 8
} 
A True Story of Death, Grief and the Law was published in 2004 and covered the trials of Anu Singh and Madhavi Rao for the poisoning murder of Joe Cinque [12]. The second, This House of Grief: The Story of a Murder Trial published in 2014, focused on the trial of Robert Farquharson for the murder of his three young sons [13]. Both are unique books; Garner's text follows her biography, a mix of creative reflection in sharp brief sentences, journalist's description and stage direction. Garner 'arranges words like still-life paintings on the page' [25: 262].

In Joe Cinque's Consolation, Garner bears witness to the inhuman horror she felt Singh's trial to be; she attended the trial at the Supreme Court of the Australian Capital Territory, observed witnesses in and out of the courtroom, visited Singh's and Cinque's parents at their homes, saw for herself Canberra's late 1990s heroin culture, and had afternoon tea with the presiding judge Justice Ken Crispin. Working these experiences into text, Garner does not emerge impartial. Garner 'inserts herself into these narratives of trauma as both witness and storyteller, creating a certain inter-subjectivity throughout her work: she witnesses others' trauma; and as a character within the texts, storyteller of those traumas' [20: 733). The act of witnessing is transformative for the artist. Initially Garner thought of herself 'as a writer at a loose end who had stumbled on something interesting' [12: 25]. She writes of her own desire 'to look at women who were accused of murder. I wanted to gaze at them and hear their voices, to see the shape of their bodies and how they moved and gestured, to watch the expressions on their faces. I needed to find out if anything made them different from me...' [12: 25]. She reflects explicitly on the ethics of what she was doing, trying to understand 'the confused drive that had been firing me, so far - first, curiosity, then a repelled fascination - even an identification - with Anu Singh; then, as I came to know the Cinques, a contagion of horrified grief' [12: 137].

Garner documented directly the trial as atomising and abstracting: 'This surgical slicing and drawing apart of concepts was almost Olympian in its remoteness. There was something frightful about it’ [12: 248]. She observes with horror as Anu Singh’s ‘inner life (or lack of it), her disturbances, her madnesses and cruelties were stripped bare and paraded before a small, intent cluster of strangers [12: 46].

In response to the horror of the 'slicing and drawing apart' of the trial, Garner presented to readers the humanity of the protagonists. A critical moment in Garner's intertextual self- 
narration was the concern she had because Singh refused to give her an interview. Garner describes how she initially explained to Mrs Cinque that in not having an interview with Singh, the journalistic expectation of 'telling both sides' should mean that the book should not go ahead. However, she changed her mind when confronted with Mrs Cinque's grief:

How could I have thought that when I couldn't bend the story to my will I could just lay it down, apologise for the inconvenience caused, and walk away? Her son's murder was not an opportunity for me to speculate on images of disharmony and disintegration. It was not a convenient screen on to which I could project sorrys of my own that I was too numb to feel. It was not even a story. It was real [12: 270].

The real of a mother's grief, a grief that was not adequately expressed and addressed in the trial, become Garner's touchstone. As Sarah Keenan points out in her review of Joe Cinque's Consolation, Garner is able to capture narrative elements that are largely outside of the scope of the formal process such as 'the feelings of loss and sorrow of those close to the victim, and to thereby provide a sense of justice that the legal system simply cannot' [21: 55]. Through Joe Cinque's Consolation the humanity of Joe Cinque as a loved son, as a young professional in Canberra in the 1990s and as a young man in an intense and unhealthy heterosexual relationship, as someone alive and not a victim, comes through. Further, Garner's own humanity, her failed marriage, her doubts about the project, her reactions to the experience, is documented. However, this does not mean it is a generous text. The humanising of Cinque and his family is not extended to Singh. Singh slides out of the text as a trope - the sensationalist, alien, horrific woman who kills. Maher, McCulloch and Pickering criticise Garner for her recycling of prejudicial stereotypes in the presentation of Singh as a 'bad sex-crazed woman driven to kill, of the woman who, by her own actions, pushes a good man to violence, and of the manipulative and scheming woman drawing others into her malign web’ [24: 237]. They note with concern that Singh as a victim of domestic violence and as mentally unwell (Singh was ultimately found to have diminished capacity and convicted for manslaughter rather than murder) - elements that could have humanise Singh - are minimised in Garner's account [24]. This is the dark side of a spectator's humanist reconstruction of a trial; there is a reservation to the artists of which creatures in the horror deserve to be reconstituted as humans.

Garner returns as a spectator to a murder trial a decade later in This House of Grief, a tighter, less indulgent text set in and around the Supreme Court of Victoria during the trial of 
Farquharson. Immediately the trial and its enviros are centre-staged. Garner writes that she approached the court building - with its traditional Greco-Roman columns and central dome [4: 146-7] - feeling 'a surge of adrenalin and a secret feeling of awe' [13: 6]. The book is dedicated to the court and derives its title from the epigraph 'this treasury of pain, this house of power and grief. ${ }^{7}$ Garner hews her storytelling closely to the experience of being in court. She records, with great sensitivity to atmosphere and drama, what it was like to sit, day by day, through the performances of the judges and the barristers, the interrogation of witnesses' character and experts, the confrontation between uneducated people of limited resource and the reach and might of the law; what it was like to try to read the jury, relaxed or distressed or stifling. Garner had the transcript of proceedings with her every night, spoke to people from the courtroom around a coffee cart, overheard other conversations adjacent to the court, and gossiped with other members of the media covering the trials to provide the substance and the fabric of her narrative. As Joseph writes, 'she is our eyes in those court rooms, trying to relate to us how to understand the initial abhorrent action - a father murdering his three young sons ... even though she cannot understand it herself.' (740). In This House of Grief the humanism is more evenly spread. The child victims and Farquharson's ex-wife, the police investigators, even the prosecuting and defence barristers, Louise, Garner's young accompanying protégé, and ultimately Farquharson, all emerge as complex, real humans. Garner reconnects the forensic details of the case -the demise of a relationship in a country town, the tracks left by Farquharson's aged white Commodore, the witnesses recalling Farquharson's behaviour before and after the vehicle plunged into the dam - into a story about human vulnerability and grief.

Garner's redeeming of the humans from the horror of the trial has a grand ambit. In Joe Cinque's Consolation and This House of Grief the trial is the loci from which Garner projects back to before the crime and forward to the lives of the players after the sentence. As a novelist and journalist whose art is the crafting of text, there seems to be a natural gravity in her works towards narrative. Where Garner is most successful at redeeming the humans from the trial is when she generates through her specific word pictures of the story across time. This is not how Isobel Williams humanises. As a sketch artist she works with the immediate image, the frozen moment in time. Even in her blog that presents exegesis on her sketches there is a precise brevity [39]. Nevertheless, although her medium and her chronological horizon is different from Garner, William’s images also humanises court protagonists.

\footnotetext{
${ }^{7}$ From Hungarian author Dezsö Kosztolányi’s Kornél Esti: A Novel, published 1936. cited in [20: 736]. 11
} 
Williams' style is fluid with sweeping strokes on selected aspects of the scene that have captured her attention. There is sense of immediacy to her sketches; that she is putting onto paper only what is essential to convey the particular moment. Whereas Garner places herself and her life into her texts, Williams' achieves an intimacy through capturing a spectator's point of view, the image from the public galleys. Williams' images are not detailed reproductions of everything that can be seen in the courtroom. Anita Lam might suggest that this is in part due to the courtroom illustrator's predicament in having to produce their sketches in a fit of activity and with speed [22: 137]. Similarly Williams' work seems to typify Lam's concept of the 'artistic flash' that is connected to 'spontaneity and urgency' driven by the moment [22: 137]. Action, speed and economy appear to be a tool of trade for the courtroom artist with Williams' noting that courtroom artists without permission to draw in the courtroom must 'take a good look then dash out to concoct an image' [37: 67].

Williams, like Garner, articulates her witnessing of courts as an outsider: 'the uninitiated stranger straying into someone else’s mystery.' [39] Williams' work captures the intersection between what is presented and what is seen. What is presented are the formal or constructed elements of the court and justice such as the barrister's wig or 'lofty white walls and velvet hangings' [39] whereas what is seen are the unintended and uncontrollable elements of justice in action and those aspects of the presentation that stand out to Williams as a spectator. It is in these partial images of the courtroom and of the actors that a sense of humanity emanates from her images.

An example is Williams’ 2016 image, Supreme Court: Fraudulent Devices. This sketch came from Williams' witnessing the hearing in the Supreme Court of the United Kingdom of Versloot Dredging BV v HDI Gerling Industrie Versicherung AG [35]. For the legal insider, this case in maritime insurance concerned whether a false representation by an insured disqualifies an entire claim as fraudulent. The decision was a win for liars, the court overruling earlier authority that knowingly presenting some falsehood in an insurance claim invalidated the entire claim [9]. Unlike Garner, who would have written about the leaky engine bulkheads in the DC Merwestone, the investigations of the insurer's lawyers Ince \& Co and the creative memory of Chris Kornet, the employee of the vessel's manager who presented the alt-truth about the bilge alarm sounding, Williams sketches the immediacy of the trial. Central is a 
behind view of counsel addressing the bench of Law Lords who sit beneath a indistinguishable occupied galley and framed, presumably oils (Figure 1). The Law Lords faces swirl with individuality and intensity, studiously focusing on the central figure. Counsel is centre stage but not central. Indeed, they can see through him. The image that immediately attracts a viewer's eye is the 'golden lining in a counsel's bespoke jacket, revealed for a few seconds when he nervously flips up the hem at the back' [38]. Communicated through the sketch is the everyday normality of a person at work, the sombre tones of professional wear displaying an inner patch of colour, and the anxiety of presenting - justifying the moral wrong of a knowing falsehood - to lined visages of authority. In this sketch Williams brings empathy and humanity to a legal scene, with counsel, the officer of the court, not a rapscallion creature, as Garner paints Lex Lasry QC Singh's defence council in Joe Cinque’s Consolation [12: 242] ${ }^{8}$, but as an individual with very human and relatable concerns.

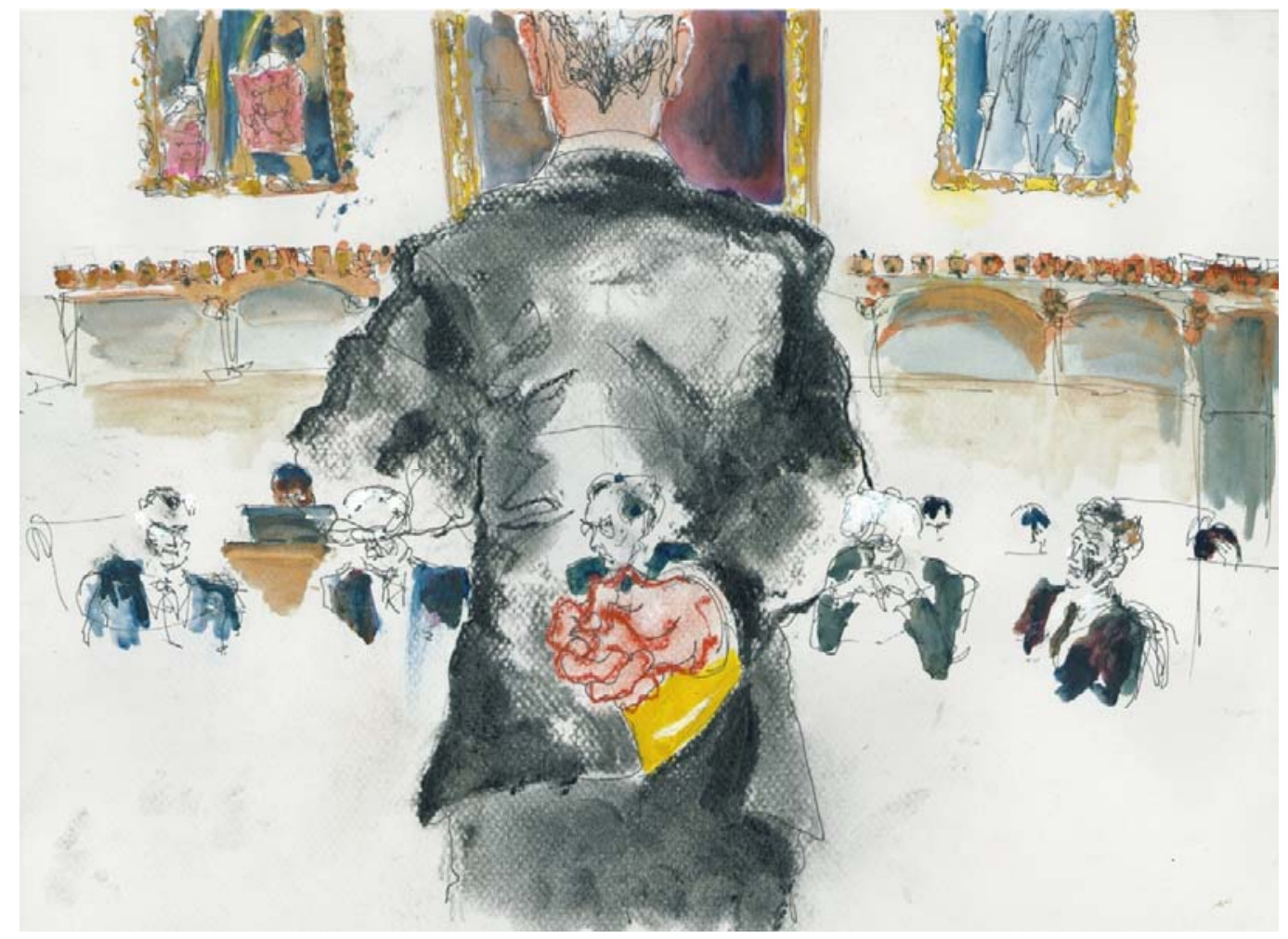

Figure 1: Isobel Williams, Supreme Court: Fraudulent Devices, 2016 reproduced with permission.

\footnotetext{
${ }^{8}$ Although she is more generous to Justice Lex Lasry presiding Supreme Court of Victoria justice at Farquharson's trial. 
Notwithstanding their differences, Garner and Williams both respond to witnessing the horror of the trial through a project of humanisation. Both try to redeem from the over burdening machinery of the trial, the humans and their lives that the machine is supposed to serve. Their witnessing involves bringing the singular lived beauty of specific individuals back into focus. Although they claim the mantle of outsiders, there is a degree of complicity in their respective projects. In humanising the trial, in providing a supplement that makes the trial and its goings on seem more human and more comprehensible, they produce work that is reinforcing of liberal legality. They are translators, nominal outsiders who reinforce the insider's desire that justice be seen to be done. Garner, as a doyen of the Australian's literary elite, who has had repeat dealings with lawyers in her own life and when working on earlier projects; most notably lawyers, courts and police when working on the Ormond College sexual harassment case that became the controversial book [32] The First Stone [11], does not come to the trials as a total outsider. Also Williams is in the court with permission. Indeed, although not employed by a media outlet, she fits within the tradition of the court artist that Lam discusses [22]. The court artist has a quasi-formal role; a select form of journalist produced by many jurisdiction's prohibition on photography in the courtroom [22: 131]. The role is generated by liberal legalities complex need for eyeballs and its concern with the power of images. In working within the role of court artist, Williams has developed a significant body of work through using the 'artistic flash' to capture the courtroom scenes. She has witnessed many courts, and her blog shows glimpses that she has a knowing, insider's knowledge of legal processes, protocols and language. In the entry on Supreme Court: Fraudulent Device, Williams, with the precision of a court reporter, presents the legal issues at trial: 'does the rule by which a fraudulent insurance claim precludes recovery under the policy apply to fraudulent means or devices? And if so, is that contrary to Article 1 of the First Protocol to the European Convention for the Protection of Human Rights?’ [38].

It is at this juncture that the images composed by Queensland artist Julie Fragar can be introduced. Fragar witnessed a murder trial in the Supreme Court of Queensland. Unlike Garner and Williams this was her first exposure to the court and to criminal trials. As a more 'out' outsider, it could be hypothesised that Fragar might produce a different set of work than redeeming humanism - that ultimately reinforced liberal legality - of Garner and Williams. Indeed, it is argued that Fragar's work is not a corrective to inhuman horror of the trial, but 
rather a critique. For her the human is in flux and contested and humanism is not redeeming. Rather there is a disorienting maelstrom of bodies and emotions and things.

\section{Fragar: Witnessing a Maelstrom of Bodies and Emotions and Things}

Fragar came to the murder trials that she observed at the Supreme Court of Queensland as more of a legal outsider than Garner and Williams. She was drawn to the court and the trial, not by a journalist's interest in women who kill (Garner) or an appreciation of the staging and theatre of the trial (Williams), but with a prior interest in the visual mechanics of intersubjectivity, of how autobiography and life narrative relate to others. For her the court was a space for what she termed 'biographical coalescence,' a space where private lives are put under scrutiny: 'The courtroom is a place where the choices we have made come together for public forensic analysis. Each preceding moment of our lives becomes preparatory for that one; who we knew, where we lived, where we went' [31: 2]. This immediately suggests that Fragar's witnessed the inhuman horror of the trial, the abstracting and atomising of human lives that Garner and Williams were also aware of. However, in the work she produced, the redeeming humanism of those artists is absent. While Fragar could intellectually comment about the humans and inhumanity of the trial, in her visual representation of the court, the human is not centre stage.

Unlike Garner's murder trials that were of notorious crimes of national interest that played to full galleys and media lenses, or Williams' Supreme Court: Fraudulent Device that has the suggestion of a crowded galley of watchful insurance brokers, maritime afficianados and shipowners attentively watching the trial, Fragar observed trials in the Supreme Court of Queensland in 2016 where her presence as an outsider was noted. In an interview with us, she relates that at each trial she witnessed, members of the victim's family and the accused's family asked her what she was doing there. She told them she was 'an artist making work about trials.' She recalled: 'The accused's family was ok with it. The victim's not so much, or at least they seemed not to like it.' She admitted to feeling 'uncomfortable.' [10]. Immediately the supposed public nature of the trial championed by liberal legality is undone. The courts she witnessed had no public, so much so, that the families of the protagonists acted as gatekeepers, interrogating and questioning her presence. 
It is this sense of an uncomfortable outsider's voyeurism that emanates from Fragar's paintings. They reproduce, sometimes quite literally, the primary and secondary images produced during the experience of witnessing a criminal trial. Her signature technique is layering - she mocks up the images initially using Photoshop’s layering function - however, as she notes, in her paintings 'there are no layers because they are woven together as one work. Not truth upon truth. All images simultaneously existing together' [10]. This layering gives a chaotic, collaged element to Fragar's work.

The outcome of her witnessing of criminal trials has resulted in two exhibitions, the first in 2017, arising from witnessing one murder trial, and the second in 2018, arising from witnessing a second trial. Both premiered at the Sarah Cottier Gallery in Sydney, New South Wales. The latter exhibition, Next Witness, which was shown from 6 October to 3 November 2018, comprised five large scale works. The paintings are essentially monochrome (blacks, whites and greys painted wet-on-wet over pink) and the style ranges from photorealism (the judge's eye in The Gatekeeper (Portrait of an Honourable Justice) (Figure 2) to primitive/figurative (the shadowy accused in The Figureheads, Figure 3) to gestural (the body of the deceased in The Gatekeeper (Portrait of an Honourable Justice) the arc of the burial mound in The Figureheads). The paintings combine primary images of the courtroom space, the architecture, people entering and leaving the court, the media waiting outside, with photographs of the artist herself, being dissected in Verdict by Committee (Group Think) (Figure 6), her face superimposed on the deceased's face as his body is laid out in a re-enactment of an image shown in evidence in Excise Wound. They include secondary images conjured up by the crime itself, including for instance, an eight-ball discussed in evidence, a SIM card that helped to ID the victim, as well as more fanciful images, such as a swooping hawk in Appearing Before the Hawks. Each of them has a movement, often circular, that captures and directs the viewer's eye, drawing them in and implicating them as secondary witnesses to the artist's prior acts of witnessing. The paintings are dominated by what Fragar identifies as 'distrust factors' [10] cameras, wigs and robes, the closed ecosystem of the jury - that triggered deep misgivings about the criminal process she was witnessing. Finally, there is a memorialising of the visuality and the organ of witnessing. An image of Fragar own eye is replicated in each painting, like a master’s signature or a ‘Where’s Wally’ pictogram search. 


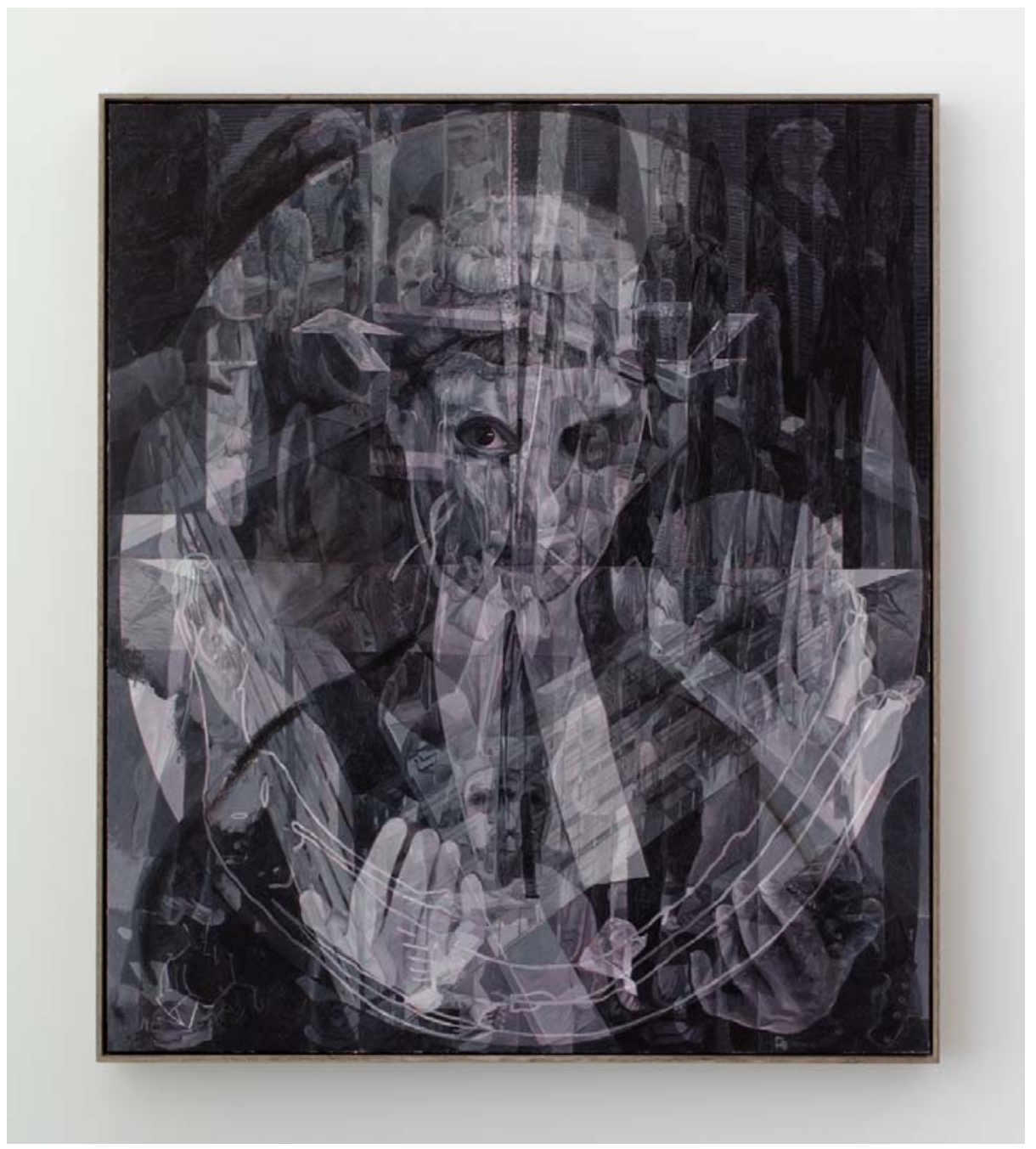

Figure 2: Julie Fragar, The Gatekeeper (Portrait of an Honourable Justice) 2018 reproduced with permission 


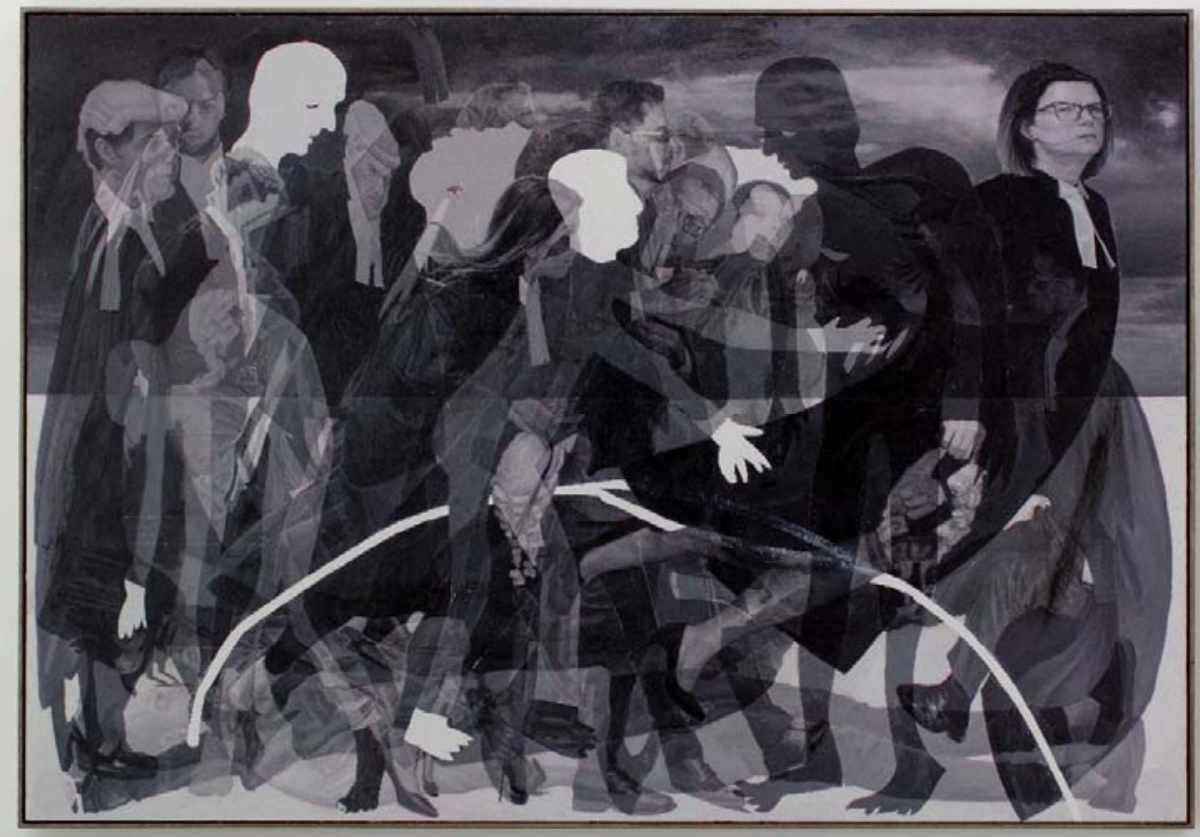

Figure 3: Julie Fragar, The Figureheads 2018 reproduced with permission

As a series of works the mix of styles, images and oppressive blacks and greys is disorientating. There is discontinuity, fracture and confusion - a swirling maelstrom of bodies, emotions and things. Fragar documents the experience of an outsider when faced with the criminal trial. What she is representing is something that is not human, although it is composed of human bodies, stories and things. The narration and the humanist gloss that can be seen in Garner and Williams is lacking in Fragar's work. Where these two artists took the shock of the abstracting and atomising of the trial and interpreted it to bring the human back into focus, Fragar embraces and extends the dark incoherence and incomprehension of the outsider's experience of a trial. This can be seen specifically in three works.

In Post-Mortem Injury (Incise Wound) (Figure 4) the possibility of humanising is present but displaced. Central is Fragar's representation of the victim laid out on a slab. The body is complete but it is a tabula that has become inscribed, noted and layered. The trial's forensic discourse, of stab points and incise wounds, has been rendered pictorially. There is nothing in the image that displaces the horror of the punctured, scribbled-on body. Fragar is emphasising that this is a deeply profane way of treating the dead. Even the face is distorted, in a 
characteristic Fragar way; the actual image of victim is underlaid with Fragar's own face. There is a touching realism to the lips that is at odds with the distorted, almost cartoon-like body and the shadowy abstract persons in the background. There is no redemption in this picture; for the victim, the expressionless background figures, or for the artist who in superimposing her image represents the self-degradation of hearing and seeing a discourse where the body was a thing. There is nothing redeeming for the viewer. This image draws in the intellect but repels the senses. Fragar captures exactly the horror of the abstracting and atomising of the trial and the negativity of being a voyeur to this process. To adapt a phrase from Katherine Biber and collaborators on the circulation of crime scene evidence outside of the courtroom, Fragar's Post-Mortem Injury (Incise Wound) represents ‘perving’ [1: 810).

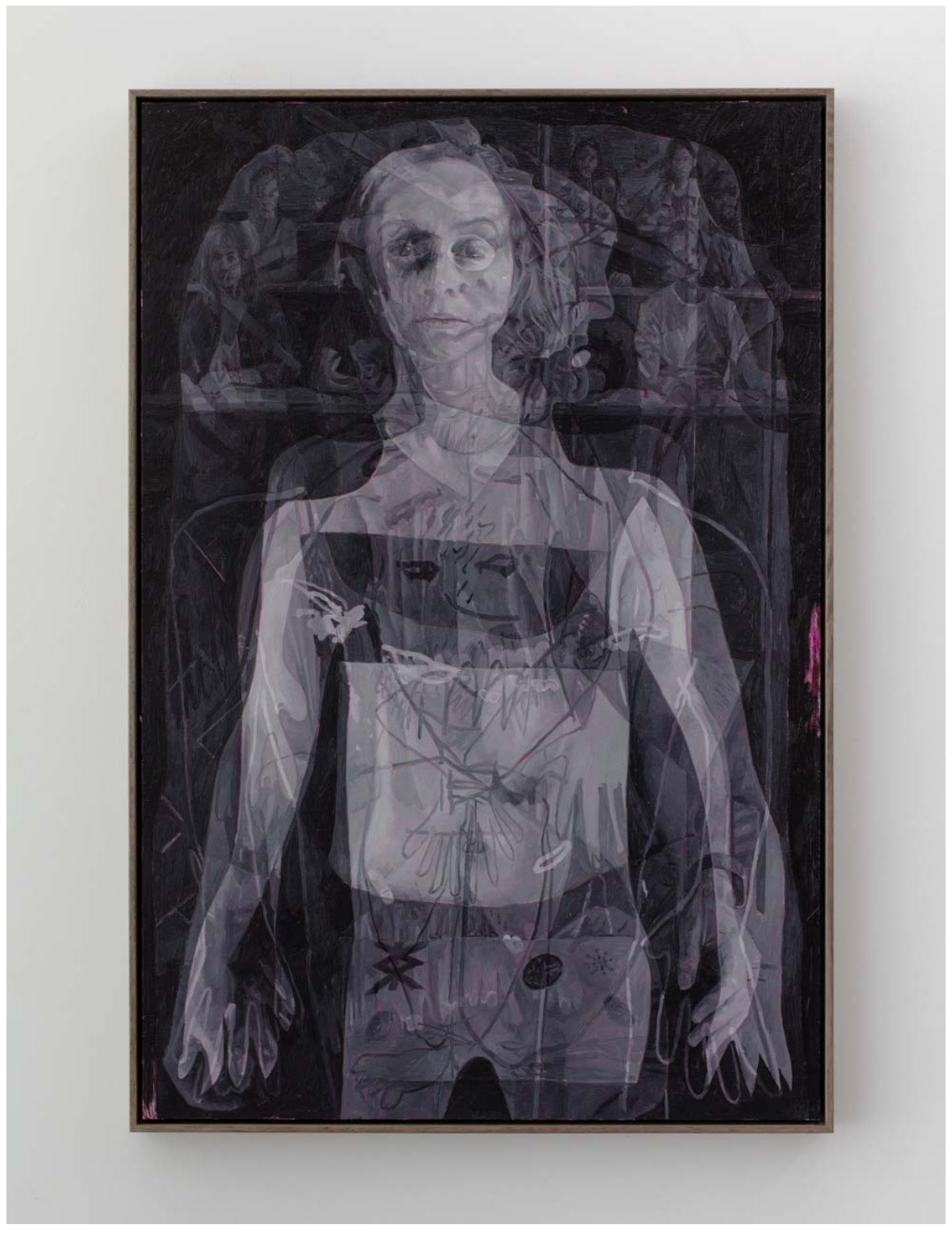

Figure 4: Julie Fragar, Post-Mortem Injury (Incise Wound) 2018 reproduced with permission. 
This commentary on witnessing is the central theme in Appearing Before the Hawks, the Hounds and Those who tell the Stories (Figure 5). Rather than the face or eye, the dominant trope of witnessing in this picture is the camera. The jumble of cameras and tripods in the painting seem crouching, animalistic, even predatory, in a kind of cinematic visual narrative that recalls the Martian tripods from H.G. Wells' War of the Worlds [36]. Fragar shows the violence and imposition of the media's mechanised seeing that has accreted over liberal legality's desire to be public. The striking façade of the Queen Elizabeth II Courts of Law that houses the Supreme Court of Queensland in Brisbane looms up high in the background. Two mirrored renderings of the artist's own son, looking young and vulnerable, contrast with the primitivism of the camera images. Fragar's own eye peers at the viewer from next to her son's image creating a sense that the painting is a surveillance infinity mirror, a regression of spectating, with the artist watching the viewer, watching a scene of stalking cameras.

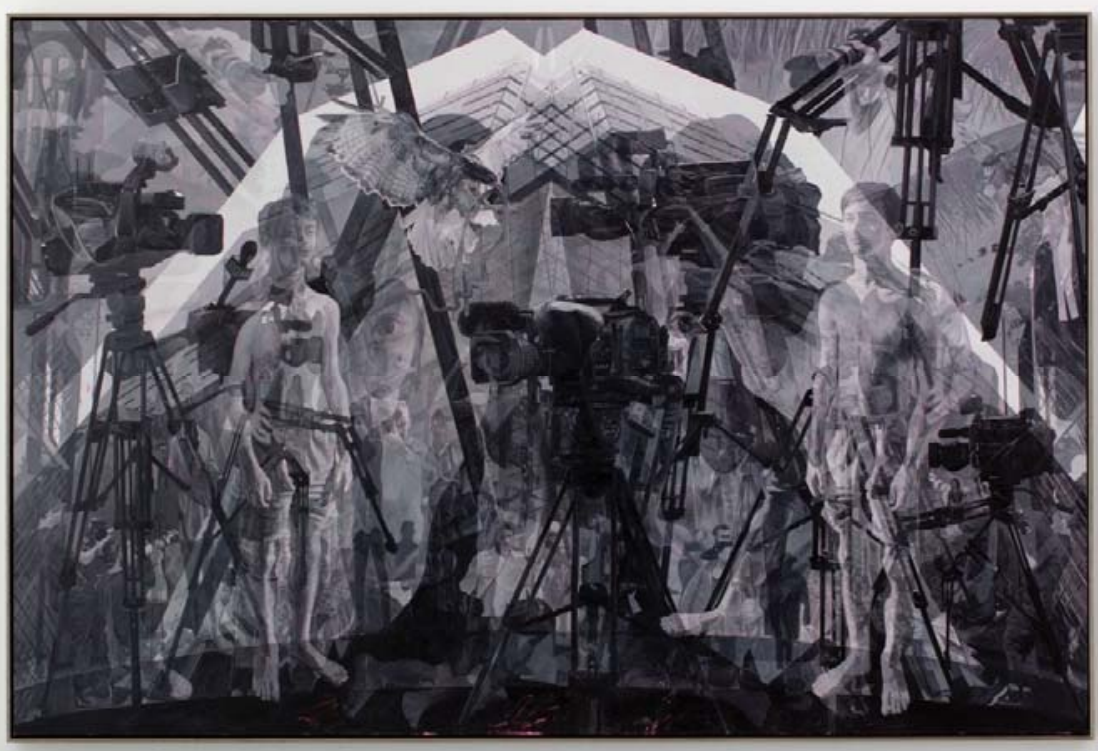

Figure 5: Julie Fragar, Appearing Before the Hawks, the Hounds and Those who tell the Stories 2018 reproduced with permission.

In Verdict by Committee (Group Think) (Figure 6) the sense of movement suggested by the tripods in Appearing Before the Hawks, the Hounds and Those who tell the Stories becomes the focus. The painting is a maelstrom. Swirling in the cyclonic currents figures representing 
the members of the jury are holding papers and pointing in different directions, clockwise and counter-clockwise, forcing energy to the centre of the frame. For Fragar, the fact that the jury sit in close physical proximity is another 'distrust factor,' as clustering them together allows them to be influenced by each other's sounds, movements and body language, which inhibits 'rigorous individual thinking' (Fragar, in Cottier, 2018). She says: "Round and round they go, the attitude of the group becoming tighter and tighter until they get to what they agree to be the centre of things. There's a body at the middle of it, at the very least.' [31: 3]. As an outsider she does not see the jury according to liberal legality's story that they represent the public and decide questions of fact constrained by laws of procedure and evidence, and free from bias. Rather Fragar depicts the jury as a behemoth in Thomas Hobbes' terms, a powerful and dangerous many-headed beast [19]. This is not a witnessing of rational decision making, of weighing evidence to determine facts beyond reasonable doubt, but a conflicted, conflicting multitude of dissent and division. The receding body in the centre is reminiscent of the figure in Post-Mortem Injury (Incise Wound). Again this is a body wearing the artist's face. The hands and arms are this time above the head, in a submissive 'do not shoot' pose, or pinned like a dissected amphibian. Indeed, dissection seems to be an obvious meaning. The black centre of the maelstrom is the figure's chest cavity, stabbed by a grey katana-like blade. 


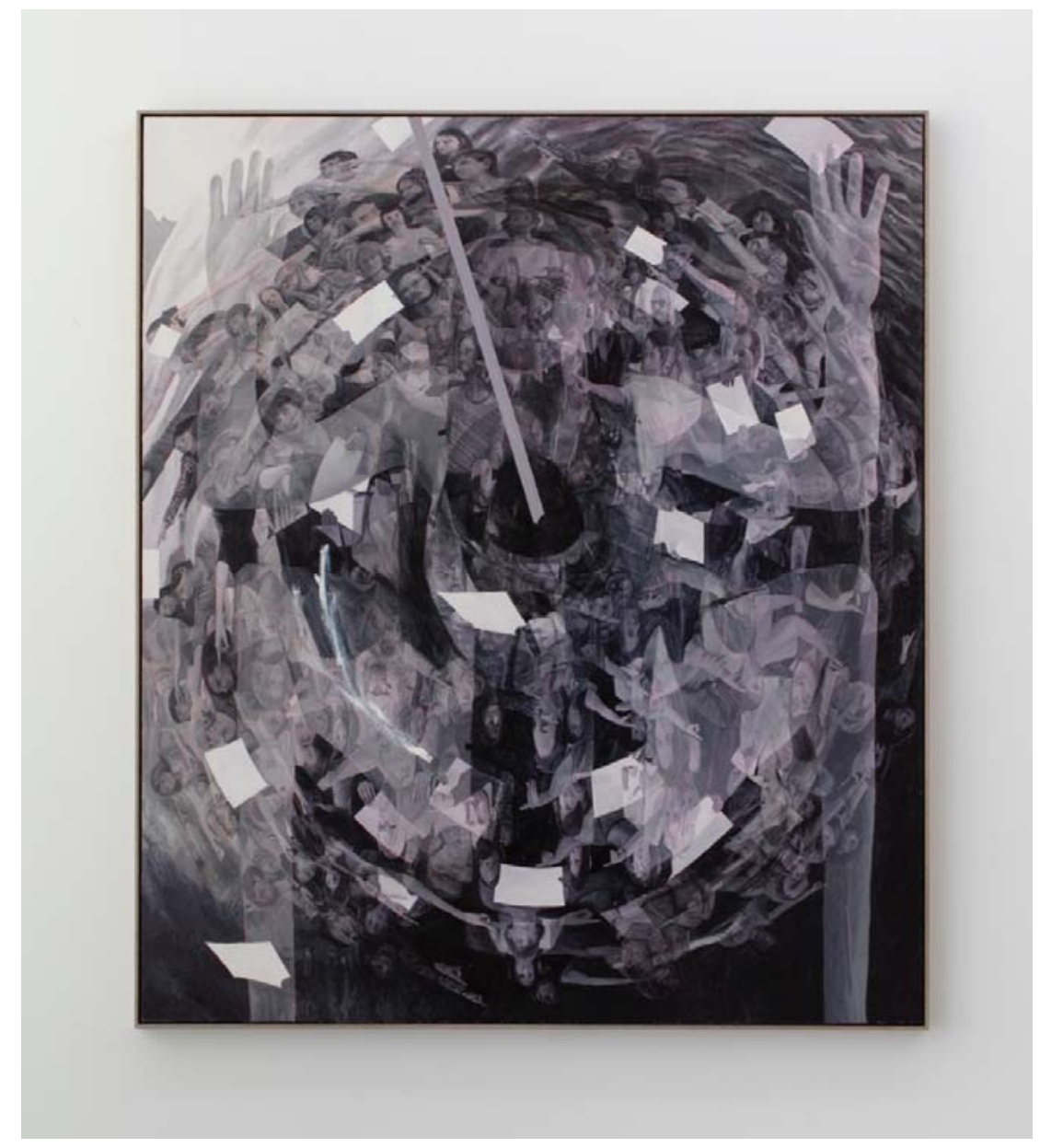

Figure 6: Julie Fragar, Verdict by Committee (Group Think) 2018 reproduced with permission.

Like the Post-Mortem Injury (Incise Wound) and Appearing Before the Hawks, the Hounds and Those who tell the Stories, there is not much comfort for viewers in Verdict by Committee (Group Think). There is a physical uncomfortableness to the eye in looking at it. The individual figures and details swirl, and it is hard to concentrate to piece together the painting as a whole. The painting is suggestive of the impossible task of the jury, of the inability to piece together the crime and victim.

Fragar's work, as suggested and enacted by her layering technique, is multidimensional. On a primary level Fragar presents the inhuman horror of the trial; the cutting up and surreal scrutinising of human lives and bodies. However, in contrast to Garner and Williams she does not present a humanist gloss reconstructing or rescuing the humans from the horrid spectacle. Instead, she takes the prima facie alienation and revulsion of the outsider and presents that to her viewers. In doing so she enacts a critique of the criminal trial as something that is un- 
redeemably inhuman, visualising the critique of the trial from the critical legal tradition. Garner paints a demonic nightmare world. The judicial portrait in the Gatekeeper (Portrait of an Honourable Justice) is a skeletal Dante-ist character. Humans as embodied selves are not the protagonists. The human body is an object, inspected, cut and interspersed with floating eyes, gestural hands, cameras, and ill-formed dark things. Time and space conflate, conflict and spin. There are monsters and violations, disconcerting movement and a lack of distinction, no colour, just blurred greys.

On the second level Fragar communicates the feeling of witnessing the demonic proceedings of the trial. There is a gut-wrenching sense of revulsion. Fragar rages against the complicity desired by liberal legality in its need of eyeball authority. This is the maelstrom that repeatedly appears in her works. The emotional impact is performative. Fragar witnesses not just the conglomeration of humans, spaces and things that compose a murder trial in the Supreme Court of Queensland, but the tainted feelings of complicity in witnessing such a spectacle. In viewing the products of Fragar's viewing, not only is there a critique of the trial as an event but a critique of the process of witnessing. Ultimately, Fragar is sharing the burden of that witnessing.

\section{Conclusion}

This paper has explored the dynamics of witnessing a trial and the tension between the legal insiders' and legal outsiders' perspectives. Liberal legality's desire for justice to be seen to be done opens the arcane space of the courtroom to outsider gazes. In doing so the meaning and messages to be taken can exceed liberal legality's script. Rather than justice being seen to be done, an outsider is more likely to see the base power of legal processes that the critical legal tradition emphasises. To see the inhuman horror of a performance where human lives and bodies are abstracted, atomised, discussed, dissected and profanely reimagined. For some outsiders faced with the horror of the trial a response is to craft a corrective story of redeeming humanism. In Garner’s and Williams' work the lived reality of the human involved in the trial is emphasised; Garner through narrative, Williams through whimsical details. For Fragar, more outsider to legal processes than Garner and Williams, the overbearing horror of the trial remains brutally central in her work. She paints legal critique. In blacks and greys, in a mishmash of styles, in objects and disembodied hands and eyes, in an often-present maelstrom, she communicates horror and disgust. There are twofold targets of her revulsion. The first is the court as a site of judgement. The second, the having to witness. These are fundamentally 
challenging critiques suggesting the profound alienation from the sensibilities of the contemporary everyday, as embodied by the legal outsider Fragar, of the norms and expectations of modern liberal legality. 
1. Biber, Katherine , Peter Doyle, and Kate Rossmanith. 2013. Perving at Crime Scenes: Authenticity, Ethics, Aesthetics: A Conversation. Griffith Law Review 22 (3):80148814.

2. Bourdieu, Pierre. 1987. The Force of Law: Toward a Sociology of the Juridical Field. Hastings Law Journal 38 (5):805.

3. Brennan, Bernadette. 2017. A Writing Life: Helen Garner and Her Work. Melbourne: Text Publishing.

4. Brigham, John. 2009.Material Law: A Jurisprudence of What's Real. Philadelphia: Temple University Press

5. Cover, Robert M. 1986. Violence and the Word. Yale Law Journal 95 (8):1601-1630.

6. Crawley, Karen. 2019. Laughed out of Court: Counter-Theatre and Participatory Justice in the Trials of William Hone. In Sound, Space and Civility in the British World, 17001850, eds. Bruce Buchan, and Pete Denney, and Karen Crawley, forthcoming. Farnham: Ashgate.

7. Dicey, A. V. 1959. Introduction to the Study of the Law of the Constitution. 10th Ed. London: Macmillan.

8. Douzinas, Costas, and Lynda Nead. 1999. Introduction. In Law and the Image: The Authority of Art and the Aesthetics of Law, eds. Costas Douzinas, and Lynda Nead, 1-17. Chicago: University of Chicago Press.

9. Eder, Bernard. 2017. The MV Good Faith: The Relevance of Good Faith in Shipping Disputes. Austlalian and New Zealand Maritime Law Journal 32:1-90.

10. Fragar, Julie. 2018. Julie Fragar Interview, 9 October, Brisbane.

11. Garner, Helen. 1995. The First Stone. Sydney: Picador Australia.

12. Garner, Helen. 2004. Joe Cinque's Consolation: A True Story of Death, Grief and the Law. Sydney: Pan Macmillian.

13. Garner, Helen. 2014. This House of Grief: the Story of a Murder Trial. Sydney: Text Publishing.

14. Gerwitz, Paul. 1996. Victims and Voyeurs at the Criminal Trial. Northwestern University Law Review 90 (3):863-897.

15. Goodrich, Peter. 1990. Languages of Law: From Logics of Memory to Nomadic Masks. London: Weidenfeld and Nicholson.

16. Goodrich, Peter. 1992. The Continuance of the Antirrhetic. Cardozo Studies in Law and Literature 4 (2):207.

17. Goodrich, Peter. 1992. Specula Laws: Image, Aesthetic and Common Law. Law and Critique 2 (2):233.

18. Graham, Clare. 2003. Law: The Architectural and Social History of the English Law Court to 1914 London: Routledge.

19. Hobbes, Thomas. 1990. Behemoth or the Long Parliament. Chicago: University of Chicago Press.

20. Joseph, Sue. 2016. Australian Literary Journalism and 'Missing Voices'. Journalism Practice 10 (6):730-743.

21. Keenan, Sarah. 2006. Reviews: Joe Cinque's Consolation. Alternative Law Journal 31 (4):54-56.

22. Lam, Anita. 2016. Artistic Flash: Sketching the Courtroom Trial. In Synesthetic Legalities: Sensory Dimensions of Law and Jurisprudence, ed. Sarah Marusek, 130-146. Abingdon: Routledge. 
23. Lemmings, David. 2012. Introduction: Criminal Courts, Lawyers and the Public Sphere. In Crime, Courtrooms and the Public Sphere in Britain, 1700-1850, ed. David Lemmings, 1-22. Farnham: Ashgate.

24. Maher, JaneMaree, Jude McCulloch, and Sharon Pickering. 2004. [W]here Women Face the Judgement of Their Sisters: Review of Helen Garner,(2004) Joe Cinque's Consolation: A True Story of Death, Grief and the Law. Current Issues in Criminal Justice 16 (2):233-240.

25. McDonald, Willa. 2011. Creditable or Reprehensible? The Literary Journalism of Helen Garner. In Literary Journalism Across the Globe, Journalistic Traditions and Transnational Influences, eds. John S Bak, and Bill Reynolds, 260-276. Amherst and Boston: University of Massachusetts's Press.

26. Menke, Christoph. 2018. Law and Violence. In Law and Violence: Christoph Menke in Dialogue ed. Christoph Menke, 3-76. Manchester: Manchester University Press.

27. Milka, Amy, and David Lemmings. 2017. Narratives of Feeling and Majesty: Mediated Emotions in the Eighteenth Century Criminal Courtroom. Journal of Legal History 38 (2):155-178.

28. Mulcahy, Linda. 2011. Legal Architecture: Justice, Due Process and the Place of Law. London: Routledge.

29. Peters, Julie Stone. 2008. Legal Performance Good and Bad. Journal of Law, Culture and the Humanities 4 (2):179-200.

30. $R$ v Davis (1995) 57 FCR 512.

31. Sarah Cottier Gallery. 2018. Julie Fragar Next Witness 6 October - 3 November, 2018. Sydney, Sarah Cottier Gallery.

32. Taylor, Anthea. 2008. Mediating Australian Feminism: Re-reading the First Stone Media Event. Bern: Peter Lang.

33. Tranter, Kieran. 2018. Living in Technical Legality: Science Fiction and Law as Technology. Edinburgh: University of Edinburgh Press.

34. Valverde , Mariana. 2015. Chronotopes of Law: Jurisdiction, Scale and Governance. London: Routledge.

35. Versloot Dredging BV v HDI Gerling Industrie Versicherung AG [2016] UKSC 45.

36. Wells, H G. 1975. The War of the Worlds. London: Pan.

37. Williams, Isobel. 2017. Drawing the Line. Proof: The Magazine of the Justice Gap 2: 6467.

38. Williams, Isobel 2016. Supreme Court: Fraudulent Devices. Drawing from an Uncomfortable Position. http://isobelwilliams.blogspot.com/ Accessed 3 December 2018.

39. Williams, Isobel nd. Drawing from an Uncomfortable Position. http://isobelwilliams.org.uk/pdf/PortoWS.pdf Accessed 3 November 2018. 